\title{
Cutaneous mastocytosis
}

INSERM

\section{Source}

INSERM. (1999). Orphanet: an online rare disease and orphan drug data base. Cutaneous mastocytosis. ORPHA:66646

Cutaneous mastocytosis is a term referring to a group of diseases characterized by abnormal accumulation and proliferation of skin mastocytes. In some cases (most commonly in adults), cutaneous mastocytosis may occur in association with mast cell infiltration of various extracutaneous organs, in which case the disorder is referred to as systemic mastocytosis (see this term). 